Article

\title{
Regressions of Breast Carcinoma Syngraft Following Treatment with Piperine in Combination with Thymoquinone
}

\author{
Wamidh H. Talib \\ Department of Clinical Pharmacy and Therapeutics, Applied Science Private University, \\ Amman 11931-166, Jordan; w_talib@asu.edu.jo; Tel.: +962-6560999 (ext. 1141); Fax: +962-65232899 \\ Academic Editor: Gernot A. Eller \\ Received: 12 May 2017; Accepted: 27 June 2017; Published: 3 July 2017
}

\begin{abstract}
Thymoquinone (TQ) and piperine, the active ingredients in cumin (Nigella sativa) and black pepper (Piper longum), respectively, exhibit various bioactivities including anticancer effects. The aim of the present study is to investigate the antineoplastic activity of a combination of TQ and piperine against breast cancer implanted in mice. The antiproliferative effects of $T Q$, piperine, and a combination of both agents were tested against mouse epithelial breast cancer cell line (EMT6/P) using MTT assay. The isobolographic method was used to calculate the combination index (CI). Degree of angiogenesis inhibition was detected by measuring vascular endothelial growth factor (VEGF) levels in tissue culture for all treatments. EMT6/P cells were inoculated in Balb/C mice and the antitumor effect of $\mathrm{TQ}$, piperine, and their combination was assessed. Changes in tumor size were calculated for all treatments. Tumor histology was examined using the hematoxylin/eosin staining protocol. Terminal deoxynucleotidyl transferase (TdT) dUTP Nick-End Labeling (TUNEL) colorimetric assay and caspase-3 activity assays were used to detect apoptosis. Serum levels of interferon (INF)- $\gamma$, interleukin (IL)-4, IL-2, and IL-10 were measured using ELISA and treatment toxicity was evaluated by measuring serum levels of aspartate transaminase (AST), alanine transaminase (ALT), and creatinine. A clear synergistic antiproliferative interaction between $\mathrm{TQ}$ and piperine was observed with CI value of 0.788 . The combination therapy resulted in significant reduction in tumor size with percentage cure of $60 \%$ and percentage death of $0 \%$. High degrees of apoptosis and geographical necrosis were induced in tumors treated with the combination therapy. Combination therapy caused significant decrease in VEGF expression and increased serum INF- $\gamma$ levels. Normal serum levels of AST, ALT, and creatinine were observed in tumor-bearing mice treated with the combination therapy. The combination of TQ and piperine acts synergistically to target breast cancer in vitro and in vivo. This novel combination exerts its effect by angiogenesis inhibition, apoptosis induction, and shifting the immune response toward $\mathrm{T}$ helper1 response. This combination therapy deserves further investigation (including measurement of hypoxia-inducible factor (HIF) $1 \alpha$ to be used in clinical studies.
\end{abstract}

Keywords: anticancer; natural products; Nigella sativa; combination therapy; breast cancer

\section{Introduction}

Cancer represents one of the main causes of mortality worldwide with an estimation of increase to 19.3 million new cases per year for 2025 . Although cancer is a global disease, more than $50 \%$ of reported cancer mortality occurs in countries with low and middle incomes [1]. One of the highly incident cancers is breast cancer, which is the most common invasive malignancy in women [2] and is characterized by high proliferation rate, resistance to apoptosis, and unregulated differentiation [3]. Current breast cancer therapies include chemotherapy, radiation, surgery, hormonal therapy, and immunotherapy [4]. Serious 
side effects were reported in patients treated with conventional anticancer therapies. These side effects include bone loss, sexual dysfunction, anemia, weight loss, and menopausal symptoms [5].

Recent studies showed that combinations of compounds with low toxicity can provide efficient anticancer therapy by targeting many pathways essential for cancer genesis and metastasis. Chemicals from plants and foods represent attractive options for such combinations because they are less toxic and more cost effective when compared with synthetic chemicals [6].

Thymoquinone (TQ) is the active ingredient of Nigella sativa. It has various biological activities including anti-oxidant, anti-diabetic, anti-allergic, and antitumor effects [7]. In its anticancer effect, TQ acts solely or in combination with other agents to induce apoptosis in targeted cancer cells $[8,9]$. Piperine is an active constituent of Piper nigrum L. and Piper longum and exhibits various activities including anti-inflammatory, immunomodulatory, anti-tumor, anti-metastatic and hepatoprotective activities [10]. Inhibitions of metastasis and tissue invasion were reported as modes of action for piperine against different cancers [11,12]. Additionally, piperine can induce apoptosis in p53-dependent pathway [13].

The poor outcome of conventional anticancer therapies against breast cancer made combination therapies a necessary option. Thymoquinone was successfully combined with other agents to improve its therapeutic efficiency against different cancers $[7,9,14]$. However, its anticancer activity was not tested in combination with piperine. Therefore, in this study, we employed a combination anticancer therapy consisting of piperine and TQ to treat breast cancer in mice. We hypothesized that piperin and TQ may work synergistically by integrating different mechanisms of action to target breast cancer implanted in mice.

\section{Materials and Methods}

\subsection{Mice}

Standard ethical guidelines were followed in this study and all experimental procedures were approved by the Research and Ethical Committee of Applied Science University (Approval Number: 2015-PHA-05). The study was conducted on 40 Balb/C female mice (4-6 weeks old, weight $21-25 \mathrm{~g} /$ mouse). Mice were kept in separate cages using wood shavings as bedding. The animal house conditions were: temperature around $25{ }^{\circ} \mathrm{C}, 50-60 \%$ humidity, alternating $12-\mathrm{h}$ light/dark cycles and continuous air ventilation.

\subsection{Chemicals, Cell Line and Culture Conditions}

Thymoquinone and piperine were provided from Sigma, (St. Louis, MO, USA). EMT6/P (ECACC 96042344) mouse mammary cell line was purchased from the European Collection of Cell Cultures. Cancer cells were cultured using minimum essential medium (MEM) supplemented with $10 \%$ fetal calf serum, $1 \%$ L-glutamine, $0.1 \%$ gentamycin, and $1 \%$ penicillin-streptomycin solution. Cells were incubated at $37{ }^{\circ} \mathrm{C}$ in $5 \% \mathrm{CO}_{2}$ and $95 \%$ humidity.

\subsection{MTT Cell Viability Assay}

Freshly growing cancer cells were harvested, washed and suspended in tissue culture media. Viability of cells was determined using trypane blue stain. Cells were dispensed (100 $\mu \mathrm{L} /$ well $)$ into 96-well tissue culture flat bottom plates at an optimized concentration of 13,000 cells / well in a complete medium. After overnight incubation, cells were treated in triplicates with increasing concentrations of TQ (10-800 $\mu \mathrm{M})$, piperine (50-1200 $\mu \mathrm{M})$, and with different combinations of TQ and piperine resulting in a final volume of $200 \mu \mathrm{L} /$ well. Treated cells were incubated for $48 \mathrm{~h}$ and cell viability was measured using 3-(4,5-dimethylthiazol-2-yl)-2,5-diphenyltetrazolium bromide (MTT) assay. In this assay, $100 \mu \mathrm{L}$ of culture media were removed from each well and replaced with $10 \mu \mathrm{L}$ of thiazolyl blue tetrazolium solution (Sigma) followed by incubation at $37^{\circ} \mathrm{C}$ for $3 \mathrm{~h}$. MTT solubilization solution (Sigma) was added to each well (100 $\mu \mathrm{L} /$ well), mixed and incubated for another hour. Absorbance was measured 
at $595 \mathrm{~nm}$ by microplate reader (Biotek, Winooski, VT, USA). Percentage cell viability was determined for all groups compared to untreated sample. Untreated cells were used as a negative control and cells treated with vincristine sulfate were used as a positive control.

\subsection{Calculation of Combination Index and Data Analysis}

The isobolographic method was used to measure the type of interaction between TQ and piperine. The combination index (CI) was calculated for combinations of TQ and piperine against EMT6/P cells and results were interpreted as described below [15]:

$$
\mathrm{CI}=(D) 1 /(D x) 1+(D) 2 /(D x) 2+\alpha(D) 1(D) 2 /(D x) 1(D x) 2
$$

where $(D x) 1=\mathrm{IC}_{50}$ of drug 1 (TQ) alone; $(D) 1=\mathrm{IC}_{50}$ of drug 1 (TQ) in combination with drug 2 (piperine); $(D x) 2=\mathrm{IC}_{50}$ of drug 2 (piperine) alone $(D) 2=\mathrm{IC}_{50}$ of drug 2 (piperine) in combination with drug 1 (TQ); $\alpha=0$ for mutually exclusive or 1 for mutually nonexclusive modes of drug action.

Interpretation of results: antagonism for CI value above 1.3; moderate antagonism for CI value of 1.1 to 1.3; additive interaction for CI value of 0.9 to 1.1 ; slight synergism for CI value of 0.8 to 0.9 ; moderate synergism for CI value of 0.4 to 0.6 ; and strong synergism for CI value of 0.2 to 0.4 .

\subsection{Anticancer Therapy on Experimental Animals}

Actively dividing EMT6/P cells were trypsinized, centrifuged, washed, counted, and suspended in complete minimum essential medium (MEM) at a density of $1 \times 10^{6} / \mathrm{mL}$. Trypan blue exclusion method was used to measure cell viability and a tumorigenic dose of 100,000 cells (suspended in $0.1 \mathrm{~mL}$ ) was injected subcutaneously in the abdominal area of each mouse. Cancer cells were allowed to grow for 14 days, and a digital caliper was used to measure induced tumors. Tumor volume was calculated using the formula $\left(\mathrm{A} \times \mathrm{B}^{2} \times 0.5\right)$, where $\mathrm{A}$ was the length of the longest aspect of the tumor and B was the length of the aspect perpendicular to A [16]. Tumor bearing mice were then randomly divided into four groups with closely matched tumor volumes for all groups. The following groups were studied: Group I: Control group (10 mice) were injected IP with vehicle (phosphate buffered saline) $0.1 \mathrm{~mL}$ daily. Group II: TQ (10 mice) were injected IP with $10 \mathrm{mg} / \mathrm{kg} /$ day of TQ. Group III: piperine (10 mice) were injected IP with $25 \mathrm{mg} / \mathrm{kg} /$ day peperine. Group IV: Combination (10 mice) were injected IP with $10 \mathrm{mg} / \mathrm{kg} /$ day TQ $+25 \mathrm{mg} / \mathrm{kg} /$ day peperine. Mice were treated for 14 days, then tumors were measured again at the end of the treatment, after which mice were sacrificed, tumors extracted, weighed and stored in $10 \%$ formalin.

\subsection{Histological Examination of Tumor Sections}

Standard hematoxylin and eosin staining procedure was used to stain dehydrated paraffin sections prepared from tumors of different treatments. Stained slides were examined using light microscope (Zeiss, Jena, Germany) equipped with a computer-controlled digital camera (Canon, Taichung, Taiwan).

\subsection{Measuring Vascular Endothelial Growth Factor Expression in EMT6/P Cells}

The effect of different treatments on vascular endothelial growth factor (VEGF) expression was measured using mouse VEGF ELISA kit (Sigma). EMT6/P cells were cultured at a concentration of $\left(1.5 \times 10^{5}\right.$ cell $\left./ \mathrm{mL}\right)$ and treated for 48 with one of the following treatments: $425 \mu \mathrm{M}$ piperine, $80 \mu \mathrm{M}$ TQ, combination of $425 \mu \mathrm{M}$ piperine $+80 \mu \mathrm{M}$ TQ and negative control which only contain MEM. Cells were processed according to the kit instructions. Briefly, cells were harvested, washed, and lysed using cell lysis buffer. Supernatants were collected and $100 \mu \mathrm{L}$ was added to each well in the 96-well microplates coated with VEGF capture antibody, then incubated for $2.5 \mathrm{~h}$. After washing, $100 \mu \mathrm{L}$ of biotinylated detection antibody was added and incubated for $1 \mathrm{~h}$ followed by washing and adding $100 \mu \mathrm{L}$ of horseradish peroxidase (HRP)-conjugated streptavidin with 45 min incubation. For color development $100 \mu \mathrm{L}$ of 3,3',5,5'-tetramethylbenzidine (TMB) substrate solution was added 
and incubated for $30 \mathrm{~min}$ in a dark place. Color intensity was measured at $450 \mathrm{~nm}$ after adding $50 \mu \mathrm{L}$ of stopping solution.

\subsection{DeadEnd TUNEL Colorimetric Assay to Detect Apoptosis}

The Terminal deoxynucleotidyl transferase (TdT) dUTP Nick-End Labeling (TUNEL) Colorimetric Apoptosis Detection System (Promega, Fitchburg, WI, USA) was used to detect the degree of apoptosis induced by different treatments. Paraffin-embedded tumor sections of different treatments were stained as described in the kit instructions. Briefly, sections were de-paraffinized followed by rehydration then fixation using $10 \%$ buffered formalin. Proteinase K solution $(20 \mu \mathrm{g} / \mathrm{mL})$ was added to each slide followed by re-fixation. Sections were equilibrated by using equilibration buffer for 5-10 min at room temperature and DNA fragments were labeled by adding recombinant terminal deoxynucleotidyl transferase (rTdT) reaction mixture at $37^{\circ} \mathrm{C}$ in a humidified chamber. The reaction was terminated using $2 \times$ SSC termination solvent provided in the kit. Color development was performed by adding horseradish peroxidase-labeled streptavidin followed by incubation with 3,3'-Diaminobenzidine (DAB) for $20 \mathrm{~min}$ in the dark. Finally, slides were mounted with glycerol and examined under the light microscope.

\subsection{Induction of Caspase-3 Activity in EMT6/P Cells}

After treatment with $80 \mu \mathrm{M}$ TQ, $425 \mu \mathrm{M}$ Piperine and combination ( $80 \mu \mathrm{M} \mathrm{TQ}+425 \mu \mathrm{M}$ Piperine), cells $\left(1 \times 10^{6} / \mathrm{mL}\right)$ were washed with ice-cold PBS and lysed using cell lysis buffer (caspase-3 assay kit, catalogue \# ab39401; Abcam, Cambridge, MA, USA). Samples were incubated on ice for $10 \mathrm{~min}$ and centrifuged in microcentrifuge at $12,000 \times \mathrm{g}$ for $5 \mathrm{~min}$ at $4{ }^{\circ} \mathrm{C}$ to precipitate the cellular debris. The caspase- 3 activity in the supernatant was measured by spectrophotometry using DEVD- $p$-nitroanilide as a substrate at $405 \mathrm{~nm}$ and according to the manufacturer's instructions provided with the assay kit. Caspase-3 activity was measured at different time intervals $(0,6,12,24,48 \mathrm{~h})$.

\subsection{Detection of IFN- $\gamma, I L-2, I L-4$ and IL-10 Serum Levels}

The effect of each treatment on the immune response of tumor-bearing mice was determined using Mouse Th1/Th2 ELISA kit (Thermo Fisher Scientific, Toronto, Canada). Blood samples were collected from mice subjected to different treatments and serum samples were prepared. Interferon (IFN)- $\gamma$, interleukin (IL)-2, IL-4 and IL-10 were detected using kit instructions.

\subsection{Determination of Aspartate Transaminase (AST) Alanine Transaminase (ALT), and Creatinine Serum Levels}

Assessment of liver and kidney functions in treated mice was conducted using instructions from commercially available kits (BioSystems, Barcelona, Spain).

\subsection{Statistical Analysis}

Data are presented using mean \pm standard error from three independent experiments. The statistical significance among the groups was determined by using one-way analysis of variance. A $p<0.05$ was considered significant. The $\mathrm{IC}_{50}$ values obtained with the different concentrations of TQ and/or piperine were calculated using nonlinear regression in Statistical Package for the Social Sciences (SPSS Inc. Released 2009. PASW Statistics for Windows, Version 18.0. Chicago, IL, USA).

\section{Results}

\subsection{Cytotoxic Effect of Piperine and/or Thymoquinone on Mouse Breast Cancer Cells}

A dose-dependent inhibition of EMT6/P cells proliferation was observed after treatment with TQ $(10-800 \mu \mathrm{M})$ or piperine (50-1200 $\mu \mathrm{M})$ with $\mathrm{IC}_{50}$ values of 390 and $870 \mu \mathrm{M}$, respectively (Table 1 ). 
Testing different combinations of piperine and TQ showed a clear synergistic interaction $(\mathrm{CI}=0.788)$ with reduction in the $\mathrm{IC}_{50}$ values for both agents to 425 and $80 \mu \mathrm{M}$, respectively (Table 1).

Table 1. The $\mathrm{IC}_{50}$ values and combination index (CI) for thymoquinone (TQ) and piperine against EMT6/P cell line.

\begin{tabular}{cccccc}
\hline Piperine IC $_{\mathbf{5 0}}$ & $\begin{array}{c}\text { Thymoquinone } \\
\text { (TQ) IC } \text { I0 }_{\mathbf{0}}\end{array}$ & $\begin{array}{c}\text { Piperine } \mathrm{IC}_{50} \text { in } \\
\text { Combination }\end{array}$ & $\begin{array}{c}\text { TQ IC }_{50} \text { in } \\
\text { Combination }\end{array}$ & $\begin{array}{c}\text { Combination } \\
\text { Index (CI) }\end{array}$ & Interpretation \\
\hline $870 \pm 5.02$ & $390 \pm 3.16$ & $425 \pm 5.11$ & $80 \pm 7.11$ & 0.788 & Synergism \\
\hline
\end{tabular}

\subsection{Inhibition of Vascular Endothelial Growth Factor Expression by Different Treatments}

The ability of different treatments to inhibit angiogenesis was evaluated by measuring the reduction of VEGF expression in cell culture. High levels $(890.4 \mathrm{pg} / \mathrm{mL})$ of VEGF were observed in the negative control group. Both piperine and TQ caused significant $(p<0.05)$ reduction in VEGF expression with VEGF levels of 177.5 and $632.7 \mathrm{pg} / \mathrm{mL}$, respectively. However, the most potent inhibition was reported in the combination therapy group with VEGF levels of $84.9 \mathrm{pg} / \mathrm{mL}$ (Table 2).

Table 2. Effect of different treatments on the vascular endothelial growth factor (VEGF) expression by EMT6/P cell line.

\begin{tabular}{cc}
\hline Treatment & VEGF $(\mathrm{pg} / \mathrm{mL})$ \\
\hline Negative control & $890.4 \pm 1.50$ \\
Thymoquinone (TQ) & $632.7 \pm 2.50^{*}$ \\
Piperine & $177.5 \pm 1.90^{* *}$ \\
Combination $(80 \mu \mathrm{M} \mathrm{TQ}+425 \mu \mathrm{M}$ Piperine) & $84.9 \pm 0.97^{* *}$ \\
\hline Compared with the negative control group, ${ }^{*} p<0.05 ;{ }^{* *} p<0.01$.
\end{tabular}

\subsection{Antitumor Effect of Thymoquinone, Piperine, and Their Combination against Breast Cancer Implanted in Mice}

Significant $(p<0.05)$ reduction in tumor size was observed in mice treated with $25 \mathrm{mg} / \mathrm{kg} / \mathrm{day}$ piperine with percentage change in tumor size of $(-15.05 \%)$ compared with the negative control group, which exhibited an increase in tumor size of (78.93\%). Treatment of tumor-bearing mice with $10 \mathrm{mg} / \mathrm{kg} /$ day of TQ resulted in greater reduction in tumor size with percentage change in tumor size of $(-26.93 \%)$. However, the highest reduction in tumor size was observed in the combination therapy group with percentage change in tumor size of $(-47.84 \%)$ (Table 3$)$. Additionally, the highest tumor regression percent $(60 \%)$ was observed in the combination therapy group, while lower percentages were observed in the groups treated with TQ and piperine with percentage regression of 30 and $10 \%$, respectively (Table 3$)$. Although piperine treatment caused a significant $(p<0.05)$ reduction in tumor size, this treatment failed to reduce percentage death observed in the negative control group (20\%). Treatment of tumor-bearing mice with TQ resulted in a reduction in death percentage to $10 \%$. This reduction was more obvious in the combination therapy group, where no death was reported (Table 3).

Table 3. Effect of Thymoquinone, piperine and their combination on tumor size, cure percentage, and survival rates.

\begin{tabular}{cccccc}
\hline Treatment & Initial Tumor Size & Final Tumor Size & \% Change in Tumor Size & \% of Cured Mice & \% Death \\
\hline Control & $275.19 \pm 28.4$ & $492.41 \pm 47.9$ & 78.93 & $10 \%$ & $10 \%$ \\
Piperine & $186.99 \pm 31.9$ & $158.85 \pm 54.3$ & $-15.05^{*}$ & $30 \%$ & $20 \%$ \\
Thymoquinone & $151.39 \pm 30.6$ & $110.62 \pm 9.1$ & $-26.93 *$ & $10 \%$ \\
Combination & $145.04 \pm 36.5$ & $75.64 \pm 19.2$ & $-47.84^{*, \#, \epsilon}$ & $60 \%$ & 0 \\
\hline
\end{tabular}

Data were expressed as the mean \pm standard error of mean (SEM). Compared with the negative control group, ${ }^{*} p<0.05$; compared with single TQ treatment group, ${ }^{\#} p<0.05$; compared with single Piperine treatment group $\epsilon_{p}<0.05$. Mice were considered cured if they had undetectable tumors in the inoculation site after $14 \mathrm{~d}$ treatment. Death percentage was calculated by counting the number of dead animals in each group during $14 \mathrm{~d}$ treatment time. 


\subsection{Induction of Apoptosis in Tumor Sections}

TUNEL colorimetric assay was used to detect apoptotic cells in tumor sections after different treatments. A limited number of apoptotic cells was observed in the negative control group. A slight increase in the number of apoptotic cells was reported in the tumor sections treated with piperine. On the other hand, TQ and combination therapy induced the highest degree of apoptosis in tumor sections (Figure 1). Further testing revealed significant elevation in the activity of caspase-3 in cells treated with TQ $(80 \mu \mathrm{M})$, piperine $(425 \mu \mathrm{M})$, and combination $(80 \mu \mathrm{M} \mathrm{TQ}+425 \mu \mathrm{M}$ Piperine). The increase in caspase-3 activity was time dependent and the highest activity was observed after $48 \mathrm{~h}$. The combination therapy caused the highest activation of caspase- 3 in all time intervals (Figure 2).
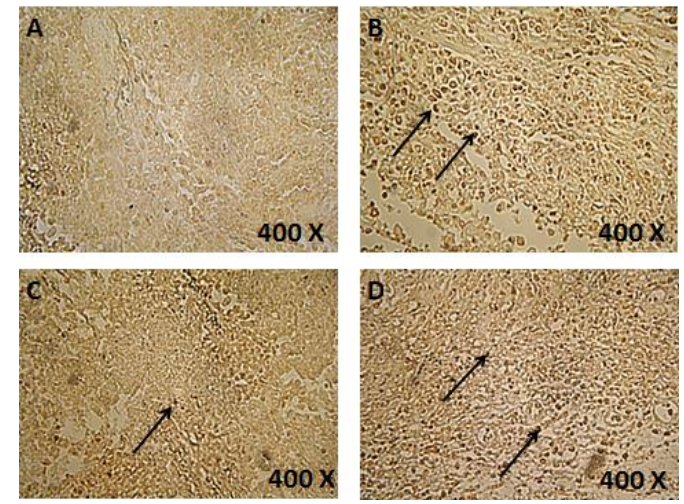

Figure 1. Colorimetric terminal deoxynucleotidyl transferase (TdT) dUTP Nick-End Labeling (TUNEL) assay for detection of apoptosis in tumor sections treated with vehicle (A) thymoquinone (TQ) $10 \mathrm{mg} / \mathrm{kg}$ (B) piperine $25 \mathrm{mg} / \mathrm{kg}$ (C) and a combination of $10 \mathrm{mg} / \mathrm{kg}$ TQ and $25 \mathrm{mg} / \mathrm{kg}$ piperine (D). Brown stained nuclei (arrows) indicate DNA fragmentation and nuclear condensation. Tumors of four mice for each treatment were examined to detect apoptosis.

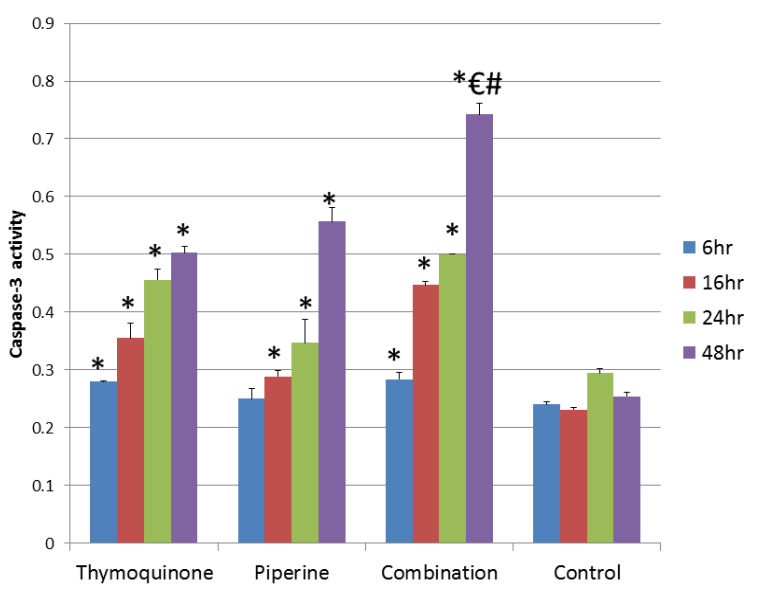

Figure 2. Activity of caspase-3 in EMT6/P cells after treatment with $80 \mu \mathrm{M}$ TQ, $425 \mu \mathrm{M}$ Piperine, and combination $(80 \mu \mathrm{M} T Q+425 \mu \mathrm{M}$ Piperine). Results are expressed as the mean optical density $(405 \mathrm{~nm}) \pm$ standard deviation (SD) $(n=3) .{ }^{*} p<0.05$ compares the treated cell with control cell; compared with single $48 \mathrm{~h}$ single TQ treatment group, ${ }^{\#} p<0.05$; compared with $48 \mathrm{~h}$ single piperine treatment group ${ }^{€} p<0.05$.

\subsection{Histological Examination of Tumor Sections}

In order to provide more details about the mechanisms of action of different treatments, tumor sections were stained using standard hematoxylin and eosin procedure and were examined to detect 
necrotic areas. Small necrotic regions (red areas) were observed in tumor sections treated with TQ or piperine. Combination therapy induced extensive necrosis in tumor sections (Figure 3).
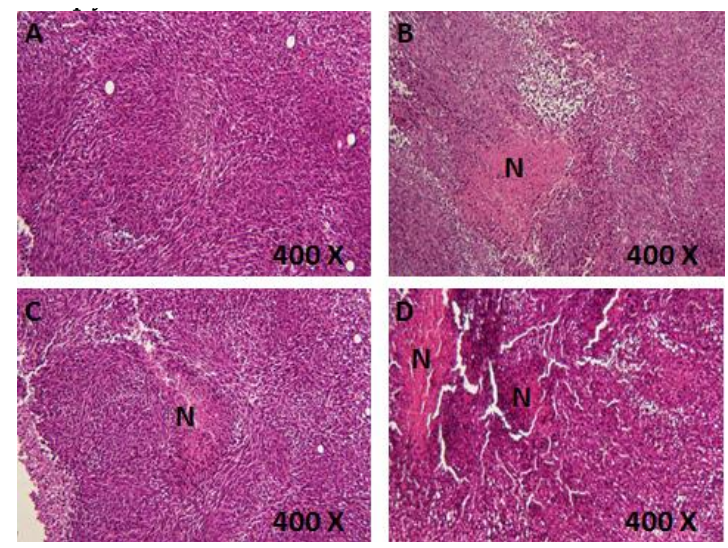

Figure 3. Hematoxylin and eosin staining of tumors treated with vehicle (A) thymoquinone (TQ) $10 \mathrm{mg} / \mathrm{kg}$ (B) piperine $25 \mathrm{mg} / \mathrm{kg}$ (C) and a combination of $10 \mathrm{mg} / \mathrm{kg}$ TQ and $25 \mathrm{mg} / \mathrm{kg}$ piperine (D). $\mathrm{N}$ : Necrotic area. Four mice were examined for each treatment.

\subsection{Effect of Piperine and/or Thymoquinone on the Immune System}

Mouse Th1/Th2 ELISA kit was used to measure the effect of different treatments on the production of IFN- $\gamma$, IL-2, IL-4 and IL-10. The highest levels of IFN- $\gamma(140.1 \mathrm{pg} / \mathrm{mL})$ were detected in the combination therapy group. Other treatments caused a slight increase in IFN- $\gamma$ levels compared with the control (29.8 pg/mL) with values of 45.8 and $68.2 \mathrm{pg} / \mathrm{mL}$ for TQ and piperine, respectively. Similar results were observed for IL-2 with the highest levels observed in combination therapy. Values of other cytokines (IL-4 and IL-10) were close to each other in all treatments (Table 4).

Table 4. Serum levels of interferon (INF)- $\gamma$, interleukin (IL)-2, IL-4, and IL-10 (pg/mL \pm SEM) for different treatments.

\begin{tabular}{ccccc}
\hline Treatment & INF- $\gamma$ & IL-2 & IL-4 & IL-10 \\
\hline Control & $29.8 \pm 0.08$ & $65.2 \pm 0.06$ & $61.1 \pm 0.06$ & $60 \pm 0.04$ \\
Thymoquinone (TQ) & $45.8 \pm 0.02^{*}$ & $85 \pm 0.02^{*}$ & $56.2 \pm 0.02^{*}$ & $51.1 \pm 0.05^{*}$ \\
Piperine & $68.2 \pm 0.18^{*}$ & $108.8 \pm 0.08^{*}$ & $44.8 \pm 0.04^{*}$ & $52.1 \pm 0.52^{*}$ \\
Combination & $140.1 \pm 0.02^{*, \#, \epsilon}$ & $158.1 \pm 0.03^{*, \#, \epsilon}$ & $55.1 \pm 0.04 *, \epsilon$ & $54.2 \pm 0.25^{*}$ \\
\hline
\end{tabular}

Compared with the negative control group, ${ }^{*} p<0.05$; compared with single TQ treatment group ${ }^{\#} p<0.05$; compared with single Piperine treatment group, ${ }^{\epsilon} p<0.05$.

\subsection{Effect of Different Treatments on Serum Levels of AST, ALT, and Creatinine}

In order to evaluate the effect of different treatments on liver and kidney functions, serum levels of AST, ALT, and creatinine were measured. All treatments caused no liver or kidney toxicity as indicated by low serum levels of liver enzymes and creatinine (Table 5).

Table 5. Serum levels of AST, ALT, and creatinine after treatment with Thymoquinone (TQ), piperine and their combination.

\begin{tabular}{cccc}
\hline Treatment & ALT (IU/L) \pm SEM & AST (IU/L) \pm SEM & Creatinine $(\mu \mathrm{mol} / \mathrm{L}) \pm$ SEM \\
\hline Thymoquinone (TQ) & $63.63 \pm 0.025^{*}$ & $24.2 \pm 1.84^{*}$ & $36.46 \pm 1.18^{*}$ \\
Piperine & $46.17 \pm 0.018^{*}$ & $18.42 \pm 2.62^{*}$ & $31.82 \pm 2.23^{*}$ \\
Combination & $40.82 \pm 0.007^{*}, t, \epsilon$ & $21.15 \pm 0.24^{*}, \#$ & $31.76 \pm 0.08^{*, \#}$ \\
Control & $75.27 \pm 0.029$ & $48.15 \pm 2.82$ & $57.17 \pm 1.63$ \\
\hline
\end{tabular}

Compared with the negative control group, ${ }^{*} p<0.05$; compared with single TQ treatment group ${ }^{\#} p<0.05$; compared with single Piperine treatment group, ${ }^{\epsilon} p<0.05$. ALT: alanine transaminase; AST: aspartate transaminase. 


\section{Discussion}

In this study, we evaluated the anticancer effect of a new combination consisting of thymoquinone (TQ) and piperine. Both agents are natural products and are proven to have anticancer effect against different cancers, including breast cancer [17-21]. However, the anticancer activity of their combination was not tested before. We demonstrated here that TQ and piperine can act synergistically to inhibit breast cancer in vitro and in vivo. The anticancer activity of this combination is mediated by apoptosis induction, angiogenesis inhibition, and modulation of the immune system. Our in vitro cytotoxicity results showed a dose-dependent inhibition of EMT6/P cells by TQ and piperine. Piperine exhibits cytotoxicity at higher concentration $\left(\mathrm{IC}_{50}=870 \mu \mathrm{M}\right)$ than $\mathrm{TQ}\left(\mathrm{IC}_{50}=390\right)$. Combination of both agents caused a reduction in $\mathrm{IC}_{50}$ values with clear synergistic effect. These results are consistent with the previous studies that reported a synergistic effect of TQ with different agents, including topotecan against colorectal cancer [18], docetaxel against prostate cancer [22], and diosgenin on squamous cell carcinoma [23]. In addition, combination of piperine with curcumin inhibited the development of hepatocellular carcinoma in rats [24] and increased the efficiency of docetaxel against prostate cancer [25].

Targeting angiogenesis is an important mechanism in cancer therapy as it reduces cancer cell proliferation by depriving the tumor of oxygen and nutrients [26]. In our study, both TQ and piperine worked synergistically to inhibit angiogenesis by lowering VEGF levels. These results agree with the recent findings that showed the ability of TQ and piperine to inhibit angiogenesis [27,28]. However, angiogenesis inhibition as a single target cannot cause complete tumor regression [29]. Accordingly, and in order to have a better understanding of the obtained results, we tried to explore other anticancer targets of this combination.

One of the main mechanisms used by cancer cells to survive is the inactivation of apoptosis. Thus, apoptosis induction is considered as one of the effective mechanisms to improve anticancer therapies [30]. A high degree of apoptosis was observed in tumors treated with TQ or combination therapy. On the other hand, tumors treated with piperine exhibited limited number of apoptotic cells. This result indicates that the main inducer of apoptosis in our combination is TQ. Our findings are consistent with other studies that reported the ability of TQ to induce apoptosis in different cancers including renal [31] and breast [32] cancers.

In order to have a better insight into other anticancer mechanisms induced by this combination, we measured serum levels of IFN- $\gamma$, IL-2, IL-4 and IL-10. IFN- $\gamma$ and IL-2 are signature cytokines of Th1 immune response and IL-4 is the main cytokine produced in Th2 immune response. Balanced ratios of Th1/Th2 cytokines are present in healthy immune systems. On the other hand, high concentrations of Th2 cytokines were observed in patients with different types of cancer [33]. Combination of TQ and piperine induced higher concentrations of IFN- $\gamma$ and IL-2 compared with single therapies. This result indicates that the combination therapy inhibits cancer cells by stimulating Th1 anticancer immune response. Such a shift in the immune response toward Th1 was reported for TQ [34] and piperine [35]. It seems that the observed anticancer Th1 immune response is a result of the combined effect of TQ and piperine.

Results obtained in the in vitro experiments were supported by in vivo results. Significant reduction $(p<0.05)$ in tumor size was observed in the group treated with the combination therapy. This combination also caused tumor regression in $60 \%$ of treated mice. Additionally, the combination therapy induced extensive necrosis in tumors and reduced the death rate to $0 \%$ compared with $20 \%$ observed in the negative control group. The high therapeutic efficiency of this combination is a direct result of activation of different anticancer mechanisms including angiogenesis inhibition, apoptosis induction, and shifting the immune response toward Th1 anticancer immune response.

Toxicity study revealed a low level of hepatic and nephro-toxicity of the combination therapy as indicated by normal levels of AST, ALT, and creatinine. Such low toxicity was expected as we used a safe concentration of TQ $(10 \mathrm{mg} / \mathrm{kg})$, which is 10 times lower than its $\mathrm{LD}_{50}$ value $(104.7 \mathrm{mg} / \mathrm{kg})$ 
reported in mice [36] and a relatively low concentration of piperine $(25 \mathrm{mg} / \mathrm{kg})$, which is also lower than its reported $\mathrm{LD}_{50}(60 \mathrm{mg} / \mathrm{kg})$ in female mice [37].

\section{Conclusions}

A combination of TQ and piperine can work synergistically to inhibit breast cancer in vitro and in vivo. The combination acts mainly by apoptosis induction, inhibition of angiogenesis, and shifting the immune response toward Th1 anticancer response. TQ is the main inducer of caspase-dependent apoptosis in this combination. Both agents work in angiogenesis inhibition and immune system stimulation. Further testing (including measurement of hypoxia-inducible factor (HIF) $1 \alpha$ levels) is needed to understand the exact mechanism of action of this combination.

Acknowledgments: The author is grateful to the Applied Science Private University, Amman, Jordan, for the full financial support granted to this research project.

Conflicts of Interest: The author declares no conflict of interest.

\section{References}

1. Ferlay, J.; Soerjomataram, I.; Dikshit, R.; Eser, S.; Mathers, C.; Rebelo, M.; Parkin, D.; Forman, D.; Bray, F. Cancer incidence and mortality worldwide: Sources, methods and major patterns in GLOBOCAN 2012. Int. J. Cancer 2014, 136, E359-E386. [CrossRef] [PubMed]

2. Torino, F.; Barnabei, A.; De Vecchis, L.; Appetecchia, M.; Strigari, L.; Corsello, S. Recognizing menopause in women with amenorrhea induced by cytotoxic chemotherapy for endocrine-responsive early breast cancer. Endocr. Relat. Cancer 2012, 19, R21-R33. [CrossRef] [PubMed]

3. Kumaraguruparan, R.; Seshagiri, P.B.; Hara, Y.; Nagini, S. Chemoprevention of rat mammary carcinogenesis by black tea polyphenols: Modulation of xenobiotic-metabolizing enzymes, oxidative stress, cell proliferation apoptosis, and angiogenesis. Mol. Carcinog. 2007, 46, 797-806. [CrossRef] [PubMed]

4. Palumbo, M.O.; Kavan, P.; Miller, W.H.; Panasci, L.; Assouline, S.; Johnson, N.; Cohen, V.; Patenaude, F.; Pollak, M.; Jagoe, R.T.; et al. Systemic cancer therapy: Achievements and challenges that lie ahead. Front. Pharmacol. 2013, 4, 57. [CrossRef] [PubMed]

5. Schover, L.R. Premature ovarian failure and its consequences: Vasomotor symptoms, sexuality, and fertility. J. Clin. Oncol. 2008, 26, 753-758. [CrossRef] [PubMed]

6. Talib, W.H. Anticancer and Antimicrobial Potential of Plant-Derived Natural Products; INTECH Open Access Publisher: Rijeka, Croatia, 2011.

7. Ganji-Harsini, S.; Khazaei, M.; Rashidi, Z.; Ghanbari, A. Thymoquinone could increase the efficacy of tamoxifen induced apoptosis in human breast cancer cells: An in vitro study. Cell J. 2016, 18, 245-254. [PubMed]

8. Gali-Muhtasib, H.; Roessner, A.; Schneider-Stock, R. Thymoquinone: A promising anti-cancer drug from natural sources. Int. J. Biochem. Cell Biol. 2006, 38, 1249-1253. [CrossRef] [PubMed]

9. Badary, O.; Nagi, M.; Al-Shabanah, O.; Al-Sawaf, H.; Al-Sohaibani, M.; Al-Bekairi, A. Thymoquinone ameliorates the nephrotoxicity induced by cisplatin in rodents and potentiates its antitumor activity. Can. J. Physiol. Pharmacol. 1997, 75, 1356-1361. [CrossRef] [PubMed]

10. Chinta, G.; Syed, S.B.; Coumar, M.; Periyasamy, L. Piperine: A Comprehensive Review of Pre-Clinical and Clinical Investigations. Curr. Bioact. Compd. 2015, 11, 156-169. [CrossRef]

11. Pradeep, C.R.; Kuttan, G. Effect of piperine on the inhibition of lung metastasis induced B16F-10 melanoma cells in mice. Clin. Exp. Metastasis. 2002, 19, 703-708. [CrossRef] [PubMed]

12. Hwang, Y.; Yun, H.; Kim, H.; Han, E.; Choi, J.; Chung, Y.; Jeong, H. Suppression of phorbol-12-myristate13-acetate-induced tumor cell invasion by piperine via the inhibition of $\mathrm{PKC} \alpha /$ ERK1/2-dependent matrix metalloproteinase-9 expression. Toxicol. Lett. 2011, 203, 9-19. [CrossRef] [PubMed]

13. Lin, Y.; Xu, J.; Liao, H.; Li, L.; Pan, L. Piperine induces apoptosis of lung cancer A549 cells via p53-dependent mitochondrial signaling pathway. Tumour Biol. 2013, 35, 3305-3310. [CrossRef] [PubMed]

14. Talib, W.H.; AbuKhader, M.M. Combinatorial effects of thymoquinone on the anticancer activity and hepatotoxicity of the prodrug CB 1954. Sci. Pharm. 2013, 81, 519-530. [CrossRef] [PubMed] 
15. Ichite, N.; Chougule, M.; Jackson, T.; Fulzele, S.; Safe, S.; Singh, M. Enhancement of Docetaxel Anticancer Activity by a Novel Diindolylmethane Compound in Human Non-Small Cell Lung Cancer. Clin. Cancer Res. 2009, 15, 543-552. [CrossRef] [PubMed]

16. Agrawal, N.; Bettegowda, C.; Cheong, I.; Geschwind, J.; Drake, C.; Hipkiss, E.; Tatsumi, M.; Dang, L.; Diaz, L.; Pomper, M.; et al. Bacteriolytic therapy can generate a potent immune response against experimental tumors. Proc. Natl. Acad. Sci. USA 2004, 101, 15172-15177. [CrossRef] [PubMed]

17. Dastjerdi, M.; Mehdiabady, E.; Iranpour, F.; Bahramian, H. Effect of thymoquinone on p53 gene expression and consequence apoptosis in breast cancer cell line. Int. J. Prev. Med. 2016, 7, 66. [CrossRef] [PubMed]

18. Khalife, R.; Hodroj, M.; Fakhoury, R.; Rizk, S. Thymoquinone from Nigella sativa Seeds Promotes the Antitumor Activity of Noncytotoxic Doses of Topotecan in Human Colorectal Cancer Cells in Vitro. Planta Med. 2016, 82, 312-321. [CrossRef] [PubMed]

19. Parbin, S.; Shilpi, A.; Kar, S.; Pradhan, N.; Sengupta, D.; Deb, M.; Rath, S.; Patra, S. Insights into the molecular interactions of thymoquinone with histone deacetylase: evaluation of the therapeutic intervention potential against breast cancer. Mol. Biosyst. 2016, 12, 48-58. [CrossRef] [PubMed]

20. Zhang, J.; Zhu, X.; Li, H.; Li, B.; Sun, L.; Xie, T.; Zhu, T.; Zhou, H.; Ye, Z. Piperine inhibits proliferation of human osteosarcoma cells via G2/M phase arrest and metastasis by suppressing MMP-2/-9 expression. Int. Immunopharmacol. 2015, 24, 50-58. [CrossRef] [PubMed]

21. Greenshields, A.; Doucette, C.; Sutton, K.; Madera, L.; Annan, H.; Yaffe, P.; Knickle, A.; Dong, Z.; Hoskin, D. Piperine inhibits the growth and motility of triple-negative breast cancer cells. Cancer Lett. 2015, 357, 129-140. [CrossRef] [PubMed]

22. Dirican, A.; Atmaca, H.; Bozkurt, E.; Erten, C.; Karaca, B.; Uslu, R. Novel combination of docetaxel and thymoquinone induces synergistic cytotoxicity and apoptosis in DU-145 human prostate cancer cells by modulating PI3K-AKT pathway. Clin. Transl. Oncol. 2014, 17, 145-151. [CrossRef] [PubMed]

23. Das, S.; Dey, K.; Dey, G.; Pal, I.; Majumder, A.; MaitiChoudhury, S.; Kundu, S.; Mandal, M. Antineoplastic and Apoptotic Potential of Traditional Medicines Thymoquinone and Diosgenin in Squamous Cell Carcinoma. PLoS ONE 2012, 7, e46641. [CrossRef] [PubMed]

24. Patial, V.; S, M.; Sharma, S.; Pratap, K.; Singh, D.; Padwad, Y. Synergistic effect of curcumin and piperine in suppression of DENA-induced hepatocellular carcinoma in rats. Environ. Toxicol. Pharmacol. 2015, 40, 445-452. [CrossRef] [PubMed]

25. Makhov, P.; Golovine, K.; Canter, D.; Kutikov, A.; Simhan, J.; Corlew, M.; Uzzo, R.; Kolenko, V. Co-administration of piperine and docetaxel results in improved anti-tumor efficacy via inhibition of CYP3A4 activity. Prostate 2011, 72, 661-667. [CrossRef] [PubMed]

26. Poleszczuk, J.; Hahnfeldt, P.; Enderling, H. Therapeutic Implications from Sensitivity Analysis of Tumor Angiogenesis Models. PLoS ONE 2015, 10, e0120007. [CrossRef] [PubMed]

27. Su, X.; Ren, Y.; Yu, N.; Kong, L.; Kang, J. Thymoquinone inhibits inflammation, neoangiogenesis and vascular remodeling in asthma mice. Int. Immunopharmacol. 2016, 38, 70-80. [CrossRef] [PubMed]

28. Doucette, C.; Hilchie, A.; Liwski, R.; Hoskin, D. Piperine, a dietary phytochemical, inhibits angiogenesis. J. Nutr. Biochem. 2013, 24, 231-239. [CrossRef] [PubMed]

29. Ma, J.; Waxman, D. Combination of antiangiogenesis with chemotherapy for more effective cancer treatment. Mol. Cancer Ther. 2008, 7, 3670-3684. [CrossRef] [PubMed]

30. Zivny, J.; Klener, P., Jr.; Pytlik, R.; Andera, L. The Role of Apoptosis in Cancer Development and Treatment: Focusing on the Development and Treatment of Hematologic Malignancies. Curr. Pharm. Des. 2010, 16, 11-33. [CrossRef] [PubMed]

31. Chae, I.; Chun, K. Abstract 4844: Thymoquinone induces apoptosis through inhibition of JAK2/STAT3 signaling via production of ROS in human renal cancer Caki cells. Cancer Res. 2016, 76 (Suppl. S14), 4844. [CrossRef]

32. Alobaedi, O.H.; Talib, W.H.; Basheti, I.A. Antitumor effect of thymoquinone combined with resveratrol on mice transplanted with breast cancer. Asian Pac. J. Trop. Med. 2017, 10, 400-408. [CrossRef] [PubMed]

33. Giannoulia-Karantana, A.; Vlachou, A.; Polychronopoulou, S.; Papassotiriou, I.; Chrousos, G. Melatonin and Immunomodulation: Connections and Potential Clinical Applications. Neuroimmunomodulation 2006, 13, 133-144. [CrossRef] [PubMed] 
34. Gholamnezhad, Z.; Rafatpanah, H.; Sadeghnia, H.; Boskabady, M. Immunomodulatory and cytotoxic effects of Nigella sativa and thymoquinone on rat splenocytes. Food Chem. Toxicol. 2015, 86, 72-80. [CrossRef] [PubMed]

35. Sharma, S.; Kalia, N.; Suden, P.; Chauhan, P.; Kumar, M.; Ram, A.; Khajuria, A.; Bani, S.; Khan, I. Protective efficacy of piperine against Mycobacterium tuberculosis. Tuberculosis 2014, 94, 389-396. [CrossRef] [PubMed]

36. Al-Ali, A.; Alkhawajah, A.; Randhawa, M.; Shaikh, N. Oral and intraperitoneal LD50 of thymoquinone, an active principle of Nigella sativa, in mice and rats. J. Ayub. Med. Coll. Abbottabad 2008, 20, 25-27. [PubMed]

37. Piyachaturawat, P.; Glinsukon, T.; Toskulkao, C. Acute and subacute toxicity of piperine in mice, rats and hamsters. Toxicol. Lett. 1983, 16, 351-359. [CrossRef]

(C) 2017 by the author. Licensee MDPI, Basel, Switzerland. This article is an open access article distributed under the terms and conditions of the Creative Commons Attribution (CC BY) license (http:/ / creativecommons.org/licenses/by/4.0/). 